\title{
Study on Total Compensation System of Independent College Teachers
}

\author{
Weihuang Dai \\ South China Business College of Guangdong University of Foreign Studies \\ Guangzhou, China 510545
}

\begin{abstract}
The instability of teachers is the most prominent problem that hinders the development of independent colleges. Through investigation, the imperfect salary system is the main reason for the instability of teachers. By improving the material incentive mechanism, the long-term development mechanism of teachers' occupation and the policy of welfare treatment, this paper builds a total compensation system for independent college teachers and provides an important guarantee for the sustainable development of independent colleges.
\end{abstract}

Keywords-independent colleges; teaching staff; total compensation; incentive mechanism

\section{INTRODUCTION}

In China, human resources have become the core resource and the most valuable asset for the socialist modernization in our country. The new generation of leaders has also put forward the people-oriented concept of respecting knowledge and respecting talents, which is the profound performance of the state in valuing talents [1]. Colleges and universities shoulder the heavy responsibility of training high-quality personnel and undertake the responsibility of promoting scientific development, technological innovation, and promoting economic and social development. Quality is the lifeline of higher education. No matter which university, quality is the core issue in the early days of development and growth. The key to improve the quality of education is the construction of teachers. The overall level of teaching staff indicates the standard of running a university and also the key factor that determines the quality of students. The French educator Emil Durkheim said: "The success of education depends on the teacher, and the unsuccessful education depends on the teacher"[2]. Without teachers, universities will not exist; without high-quality teachers, high quality universities will not exist.

According to the school system, China's higher education is divided into two categories: one is the state-owned public universities; one is private colleges and universities. Independent college is a form of private colleges and universities refers to the undergraduate-level college under the new mechanism and mode. It is an exploration and innovation of higher education running mechanism and mode under the new situation and an effective way to expand the resources for higher education, which is of great significance to the sustained and healthy development of our country's higher education in the future. South China Business College is an independent college which is run by Guangdong University of Foreign Studies and is approved by the Ministry of Education. The scientific teacher salary system is the key to the construction of teaching staff and an important guarantee for the sustainable development of independent colleges. This paper mainly studies the construction of total compensation system of teachers in South China Business College, hoping to provide reference for similar colleges and universities.

\section{TOTAL COMPENSATION}

Since the mid-1990s, WAW (World at Work) has proposed Total Compensation, which is composed of five elements: wages, social security fund and other benefits, job performance and recognition, career development channels and opportunities, working environment and living atmosphere [3]. These five elements complement each other and supplement each other. According to the needs of the construction of qualified personnel, unit managers can select and adjust the salary management philosophy from the elements of total compensation, in order to promote employees' high satisfaction and high output rate, so that the organization can motivate and retain talents and employees can grow, and finally achieve a win-win outcome for the organization and employees.

Some of the five elements of total compensation are nonmonetary expenditures. Management department can use some non-monetary salary to balance employees' discrepancies in material incomes such as wages, which can meet the needs of employees through smaller investments and enable employees to get satisfaction with the job. In this sense, total compensation can save costs [4]. In the 21st century, with the social and economic development, people's needs do not remain at the material level any longer. According to Maslow's theory of hierarchy of needs, the need for development and respect will appear after the material needs are met. When they feel that wages are right, they will strengthen the pursuits of long-term development of a relaxed working environment and personal career and better living environment and other aspects. Therefore, total compensation model has become a kind of remuneration payment method which adapts to today's society, enabling enterprises and employees to achieve a win-win situation. 


\section{THE CURRENT SALARY SITUATION OF TEACHERS OF INDEPENDENT COLLEGES}

According to the Fair Theory of American scholar Adams, only fair salary can play an incentive role for employees. Once the horizontal and vertical comparisons show that their salary is not satisfied, their psychological situation will be imbalance. Then they will take measures or even leave the position to restore their mentality balance [5]. In general, independent college teachers are highly educated with a strong sense of enterprising and sense of accomplishment. When compared with others, their own situation is not as good as that of the ones with comparable academic background, their own units are private and their wages are lower than others, which will result in psychological imbalance. As a result, $43.5 \%$ of the teachers choose "a job that supports their families" when being asked "why you choose to work as an independent college teacher?" Therefore, a considerable part of the independent college teachers take the teaching career as a mean to make a living, rather than a lifelong career development, and they also neglect the value of education in this great cause. They do not form a firm sense of professional pride inside. Although teachers from independent colleges always leave the position because they take examinations of doctor or civil servants or choose high-income units which on the one hand, show that the employment mechanism is flexible, but on the other hand, the excessive loss is affecting the sustainability of development of independent colleges. In this regard, the author conducted a survey on salary satisfaction of teachers of South China Business College.

TABLE I. TEACHERS' SATISFACTION SURVEY OF SALARY SITUATION

\begin{tabular}{|c|c|c|c|c|c|c|}
\hline $\begin{array}{l}\text { Survey } \\
\text { subject }\end{array}$ & Questionnaire & $\begin{array}{c}\text { Not at } \\
\text { all }\end{array}$ & $\begin{array}{c}\text { Not in } \\
\text { line }\end{array}$ & $\begin{array}{c}\text { Not } \\
\text { clear }\end{array}$ & $\begin{array}{l}\text { More } \\
\text { in line }\end{array}$ & $\begin{array}{c}\text { Complete } \\
\text { in line }\end{array}$ \\
\hline \multirow{4}{*}{$\begin{array}{l}\text { Salary } \\
\text { system }\end{array}$} & $\begin{array}{l}\text { Your salary matches } \\
\text { your work }\end{array}$ & $10.1 \%$ & $45.2 \%$ & \begin{tabular}{l|l}
15.3 \\
$\%$
\end{tabular} & $20.6 \%$ & $8.8 \%$ \\
\hline & $\begin{array}{l}\text { You are satisfied } \\
\text { with your salary } \\
\text { compared to other } \\
\text { colleagues of the } \\
\text { college }\end{array}$ & $30 \%$ & $40.2 \%$ & $3.1 \%$ & $13.5 \%$ & $12.2 \%$ \\
\hline & $\begin{array}{|lrr|}\text { You are } & \text { satisfied } \\
\text { with your } & \text { salary } \\
\text { compared } & \text { to } \\
\text { colleagues } & \text { of } & \text { other } \\
\text { colleges } & & \\
\end{array}$ & $45.1 \%$ & $23.3 \%$ & $\begin{array}{l}12.8 \\
\%\end{array}$ & $10.5 \%$ & $8.3 \%$ \\
\hline & $\begin{array}{llr}\begin{array}{l}\text { There are } \\
\text { benefits }\end{array} & \begin{array}{r}\text { good } \\
\text { and }\end{array} \\
\text { allowances of } & \text { the } \\
\text { college } & & \\
\end{array}$ & $10.1 \%$ & $45.2 \%$ & $\begin{array}{l}15.3 \\
\%\end{array}$ & $20.6 \%$ & $8.8 \%$ \\
\hline
\end{tabular}

As can be seen from "Table I", 55.3\% of teachers think that their salary is not proportional to their own work. Only $29.4 \%$ of teachers think their salary and their work are match. Compared with other schoolmates of the college or the friends of other similar colleges, the satisfaction rate of their own salary are $25.7 \%$ and $18.8 \%$, while the non-satisfaction rate are $60 \%-70 \%$. It can be concluded from the above data that the most teachers think that their salary is not in direct proportion to their own work either horizontal or vertical. This is also the most fundamental economic factor driving the loss of teachers in independent colleges.

\section{THE CONSTRUCTION OF TOTAL COMPENSATION SYSTEM}

Independent college teachers belong to the higher education or higher undergraduate qualifications or higher level talents, the traditional single material treatment cannot meet the needs of independent college teachers. To retain talented people and make talented people find a sense of belonging, attention shall be paid on the five elements of total compensation and construct a comprehensive salary system for independent college teachers according to the demand theory [6].

\section{A. Material Incentives Mechanism[7]}

In view of the status quo of teachers in independent colleges and the development strategies of specific independent colleges, colleges shall ensure the appropriate and reasonable growth of the general level of teaching staff based on keeping with the development of the college and matching the growth of education fees. College shall also design the maneuverable salary system which has effective motivation, in order to provide decent retired life to top talents.

1) The amount of teachers' salary shall be determined by the actual situation with the college: In salary strategy, the amount of salary is determined by considering the characteristics of the industry and the region. There are three strategies for determining the amount of salary for an organization: market leading strategy, market following strategy and mixed salary strategy. The independent colleges that are still in the development stage adopt the market leading strategy and need sufficient and relatively stable funding sources. Independent colleges have a single funding which is subject to the large number of students enrolled in the year with a certain degree of risk. The adoption of market leading strategic will be constrained by funds. It is difficult for the market to follow strategies to introduce and retain high-level teachers. Therefore, independent colleges which are in the development stage shall determine the compensation strategy according to the actual situation of their own development. Mixed salary strategy is to use different salary methods for different departments, different positions, different talents within the college.

2) Design a salary system fitting the needs of college development and teachers' needs: According to its own development orientation and personnel training objectives, the college shall determine the human resources management strategy. Under the guidance of human resources management strategy, the college shall develop a specific salary system.

First of all, in the early days of the establishment of an independent college, teachers are mainly responsible for teaching. There was basically no amount of scientific research work. The salary is determined by the amount of class hours. Teachers are also called "knowledge-piece workers in the new era." Since the establishment of the 
independent college, the state and provincial education departments have put forward the evaluation requirements. Among them, the ability and level of teaching and research is one of the most important indicators in the testing and evaluation. In order to promote teachers' good performance in teaching and research work, independent colleges are required to change the previous single salary system based on workload and establish a floating salary system that combines basic and incentive salary.

Second, the current independent college is composed of the following teachers: teachers who have just graduated, middle-aged and young backbone teachers, and associate professors who are retired. In accordance with Maslow's hierarchy of needs, teachers shall be motivated, and their needs shall be understood. Retired associate professor or above teachers' desire should be respected. Their salary system shall be dominated by explicit compensation with appropriate other welfare. Middle-aged backbone teachers need to take care of the elderly and children in families, they are not only in the pursuit of economic interests and guaranteed economic source, but also in the pursuit of career development and success. Their salary system shall be total compensation. The newly graduated teachers firstly choose units and mainly pay attention to the salary each month. As they just graduate, economic needs are their main concerns. They also do not understand the colleges they are working in and do not have much feeling of the colleges. Teachers of independent colleges may be just their temporary work. If the salary is not competitive, they will prefer higher-wage units, such as foreign enterprises, stable units, civil servants or public institutions. Only after some years of independent experience in independent colleges can some teachers be able to work in independent colleges relatively stable for a long time. Their salary system is based on the basic salary and the state-prescribed social insurance.

Finally, the gap between the status of college teachers and the requirements of personnel training shall be clarified, and the key issues to be solved in the construction of teaching staff shall be clarified, so that the salary design can properly apply the effective salary theory to guide colleges to establish the salary system framework.

3) Improve teachers' hidden salary, fully mobilize the initiative of independent college teachers and gradually develop the sense of ownership: In order to be able to attract teachers, especially key teachers, in the early years of schooling, independent colleges pay more attention to their external competitiveness in the design of their salary systems. However, economic incentives are short-term to individuals and require implicit compensation as long-term incentive protection.

Independent college teachers belong to the high-level intellectuals. In addition to material salary, teachers in independent colleges are more concerned with the development of personal professions, innovations in teaching and scientific research, being respected and other implicit salaries. Therefore, in designing the salary system, the combination of implicit and dominant salaries shall be paid attention to, in order to guide teachers to unify the goals of individual career development with the objectives of the college and increase the investment in teaching and research conditions and training to meet their related needs.

\section{B. Teachers Career Long-term Development Mechanism}

Give full play to the education, training and management functions of the teacher development center, and strengthen the education and training of independent college teachers' professional identity. On the basis of this, based on the characteristics of teachers at different levels, hierarchically carry out diversified and three-dimensional training development path with plan with a convergence of international and domestic, which is suitable for the professional development of teachers of different levels and is a combination of training and practice, career professionals and interdisciplinary. At the same time, increase the input of human capital and improve the quality and effectiveness of human resources [8]. Improve teaching, research and management skills.

1) Strengthen teachers' professional identity education: The strong sense of identity of college teachers in their careers can enhance their self-confidence in undertaking education so as to reduce the attention paid to material treatment. Therefore, the independent college can strengthen teachers' ideological and political education, help teachers to strictly resist the influence of social unhealthy atmosphere and reshape the professional dedication, all of which needs to be completed by teacher education which is one of the effective ways to solve the problem of lacking of motivation.

2) According to the different levels of teacher characteristics, implement career planning guidance: Teachers' career planning refers to the combination of teachers and universities. Based on the self-understanding, analysis and summary of the main and objective conditions of the individual's own career, the career goals that he or she ultimately needs to achieve are determined. Taking teacher development center as a platform, help teachers to understand themselves objectively. Provide different paths or platforms for teachers with different levels. Actively guide teachers fully consider their own daily work and living reality in the development and realization of their life career planning goals, in order to promote the harmonious development of work and families.

3) According to demand, carry out flexible and informative training: In order to realize the career development plan for independent college teachers, the individual development shall be combined with the organizational training system, and colleges shall carry out targeted training activities according to the needs of different types of teachers.

a) New recruits teachers: New teacher training carries out the basic knowledge of teaching and research, basic skills education and practice, mainly pre-job training and job training. Pre-job training includes education laws and regulations and policies, education, basic theory of 
psychology, teacher job requirements and so on. Carry out job training to the new full-time teachers each year. Teachers with experience of independent colleges shall guide the teaching training. Develop guidance work plan according to the characteristics of training objects and training requirements, to help trainees to have a better teaching performance and improve the quality of classroom teaching. Every week, trainees will be randomly tested and be guided. Trainees can also randomly learn experience in the class of the experienced teachers each week. Trainees can actively study independently according to their actual conditions. After one cycle is completed, colleges will hold assessment targeted and urge new recruits teachers to grow in motivation and pressure.

b) Young and middle-aged backbone teachers: Young teachers who have been working in colleges for more than two years or possess mid-level professional and technical titles shall focus on developing professional skills and basic theoretical knowledge, focusing on improving their teaching, scientific research ability and practical ability. Mainly adopt the following forms: According to the needs and plans, participate in training courses, short courses and single section training to improve their teaching level or send to overseas for training. Teachers with intermediate professional titles for more than three years may be arranged for domestic visiting scholars to participate in teaching and research projects as needed. Teachers who have intermediate professional titles for more than five years and who can fulfill their job responsibilities may, in principle, be arranged for short-term training in the form of rotational training and participate in high-level international and domestic academic exchanges and seminars.

c) High-level talented teachers: The high-level personnel teaching staff shall be trained to be familiar with and grasp the subject and the development of cutting-edge information in the field mainly through the teaching and research work practices and academic exchanges, to further improve the academic and administrative level. Mainly adopt the following forms: Participate in the curriculum and teaching reform, short-term seminars and classes of teaching construction and practical skills. In combination with the scientific research tasks, participate in advanced courses for cutting-edge disciplines, attend academic conferences at home and abroad, conduct inter-school academic exchanges, or be sent to training abroad. Teaching staff with senior professional and technical positions shall improve academic standards mainly through high level of scientific research and teaching work. Its main forms of training are to attend academic conferences at home and abroad, exchange lectures, short-term visits and cooperative research.

4) Support and encourage faculty and staff to enhance their academic degree: In the early stage of development of independent colleges, due to many reasons, the introduction of teachers is mainly master's graduate students. Most of them have become the backbones of independent colleges after working for some time. In order to better develop human resources and ensure the rapid development of qualified personnel, at the same time, in order to strengthen the sense of belonging of these teachers, independent colleges can adopt flexible policies to retain some excellent talents who are admitted as doctoral candidates.

\section{Policy Support for the Same Benefits}

The benefits of independent college teachers, especially the retirement pensions, are quite different from that of teachers of public schools, which is one of the important reasons for the loss of teachers. In order to prevent the loss of teachers, it is suggested that the managers of independent colleges shall be prepared for the two aspects: On the one hand, the managers of independent colleges take a highly responsible attitude toward teachers and start from the concept of long-term schooling, call for the government to clean up the policy of discrimination against independent college teachers, refine and implement the social security policies of independent college teachers, and solve the teachers' worries, so as to achieve the purpose of stabilizing teachers. Independent colleges are quasi-public welfare undertakings, and the government has the responsibility to protect the rights and interests of independent colleges and their teachers, which provides a policy basis for the independent colleges' appeals. On the other hand, although the current state is implementing the merger of retirement and pensions, at present, the retirement pensions of independent college teachers are much less than that of the pensions of civil servants or institutional retirees. While independent colleges are waiting for the state to solve their problems, they can explore the supplementary issues of establishing retirement teacher's pension to attract and stabilize their talents.

\section{CONCLUSION}

As a new force, Independent College has made important contributions to the development of China's higher education and its development deserves the attention of every educator. Total Compensation system for independent college teachers proposed in this paper has been tried for 2 years in South China Business College of Guangdong University of Foreign Studies and has achieved good results, which is mainly reflected in the steady trend of teachers and the marked improvement of teachers' professional accomplishments. Total Compensation system will be further improved through the reform of labor contracts and other measures.

\section{REFERENCES}

[1] B. Jing, "On people-oriented management concept," J. Economic and Technical Cooperation Information, May 2014, pp. 19-22.

[2] J.M. Lin, "Strengthening the Construction of Teaching Staff in Applied Universities,” J. Development Research, April 2008, pp. 9596.

[3] Warwick Talent Network, "Total Compensation Consists of Five Elements". http://www.hwhr.cn/zhichang/a4539.html, March 2016.

[4] F.Hao and S. Wu, "Call Central Total Compensation Strategy Application,” Mrs. East China Normal University, 2013.

[5] X.T. Zhang, "Total Compensation and Its Role," J. Human Resource Management, May 2016,pp.136-137. 
[6] Y.Fu, "Construction of Teaching Staff in Higher Vocational Colleges from the Perspective of Total Compensation," J. Vocational and Technical Education, August 2016, pp. 54-58.

[7] C.K. Tang, "High commitment human resource management," J. Business Administration, Augus 2016, pp.104-104.

[8] W.J. Cui, L.N. Wang and F. Chen, "Research on Wages and Incentives for Sci-tech Staff Based on Total Compensation Perspective," J. Science and Technology Management Research, February 2015, pp.83-86. 